\section{Out, damn Spot}

$\mathrm{T}$ he Canadian Lung Association will escalate its lobbying effort to persuade Canada's airline industry to remove pets from passenger cabins to protect people with severe asthma and pet-related allergies.

"We get that people want to travel with their pets but we just don't understand why people need to travel with their pets in the cabin of an airplane," says spokesman Cameron Bishop. "This is not to be unsympathetic to pet owners but our first responsibility is to people with respiratory problems."

Air Canada recently opted to become more pet-friendly by rescinding its 2006 ban on small pets travelling in passenger cabins, provided they are contained within small cages or kennels that fit under a seat. Service animals remain exempt, as they were during the period in which Air Canada prohibited pets in cabins.

Bishop says the association wants small, nonservice animals placed in the same pressurized, heated cargo bay compartments that now house larger pets that travel.

The association organized a letterwriting campaign calling on the House of Common's Standing Committee on Health Care to examine pet-friendly airline policies. The campaign does not address the issue of limits on passenger use of perfume, which many Canadians say is as great, or even greater, an irritant. But Bishop says there is a chance that the association would raise the issue should Parliament agree to hearings on banning small pets from airline cabins.

Bishop says it is ironic that Air Canada rescinded its prohibition on small pets travelling with their owners, given that the airline went nut-free several years ago to protect passengers with severe allergies. Only $1.5 \%$ of Canadians suffer severe nut allergies, while $8 \%$ of Canadians over the age of 12 suffer from severe asthma and nearly a third suffer from allergies of some sort.
The lung association says its campaign is augmented by a national public opinion poll that found $80 \%$ of Canadians want airlines to offer pet-free flights, while nearly three-quarters believe the federal government should step into the fray.

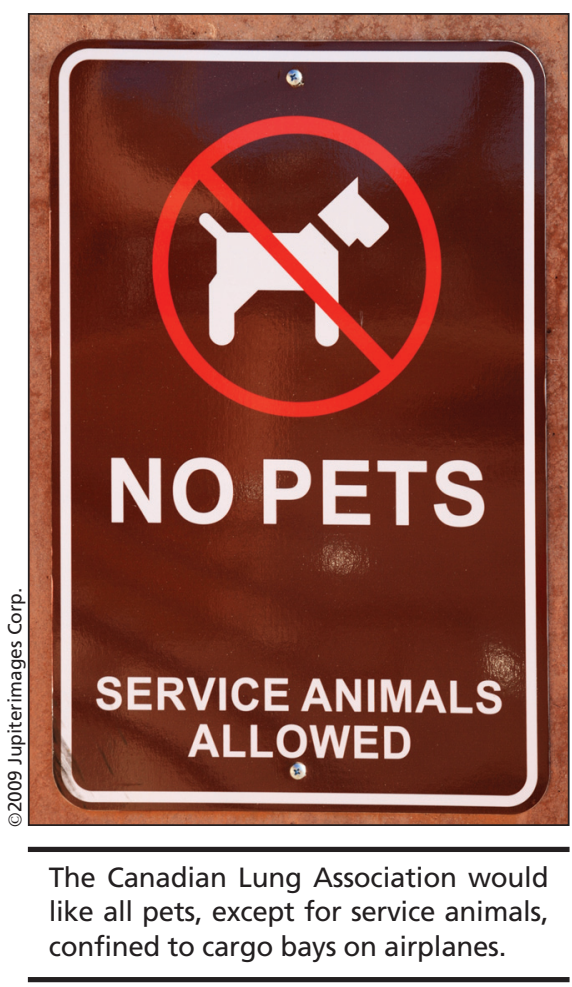

Also calling for prohibitions on pets in passenger cabins were delegates to the Canadian Medical Association's recent annual general meeting in Saskatoon, Saskatchewan.

Resolution sponsor and Newfoundland and Labrador Medical Association President Dr. Brendan Lewis argues that a ban should be introduced, if only to prevent one passenger from becoming sick.

While there have not been a great number of documented cases of asthmatic passengers suffering attacks after being exposed to pets in close quarters, the high incidence of asthma and environmental allergies justifies a move to limit pets, he says. "If there is a chance that even one person could become seriously ill from being exposed to a pet on a flight, then we have to be diligent and pursue policies and practices to protect those people."

Lewis adds that a search of medical literature reveals no definitive findings on the health impacts of pets on flights. He also notes that no one has been able to determine whether the air circulation systems in modern aircrafts diminish the threat from pet dander, or increase the threat as air is recirculated through the passenger cabin.

The lack of conclusive evidence appears to lie at the heart of Air Canada's decision to become more petfriendly.

Spokesman Peter Fitzpatrick says the airline is confident that a limited number of small pets on flights does not present a significant health risk to asthmatic passengers. He adds that the majority of the world's airlines allow small pets in passenger cabins and there have been very few reported cases of other passengers suffering from asthma attacks or other respiratory ailments.

Fitzpatrick also notes that the United States Federal Aviation Authority research concluded that the clothes of pet owners present more of a risk to asthma-prone passengers than the pets themselves.

Even if pets were banned from passenger cabins, it is impossible to ensure that flights are free of pet dander, Fitzpatrick adds. "For most of our history, we've carried pets in our cabins. It's a long-standing position and it's widespread in our industry."

Calgary, Alberta-based WestJet Airlines has never banned pets from passenger cabins and has no current plans to do so. But spokesman Robert Palmer says the airline would consider potential compromises to protect passengers with respiratory ailments, should the Canadian Lung Association make a pitch for restrictions. - Dan Lett, Winnipeg, Man.

DOI:10.1503/cmaj.109-3045 